\title{
PENGARUH KEPERCAYAAN DAN KEMUDAHAN TERHADAP KEPUTUSAN PEMBELIAN BELANJA SECARA ONLINE
}

\author{
Meri Sandora \\ UIN SUSKA Riau \\ E-mail: meri.sandora@gmail.com
}

\begin{abstract}
Penelitian ini dilakukan pada mahasiswa yang berbelanja secara online pada websitewebsite berbasis aplikasi pada internet. Adapun Jenis data yang digunakan dalam penelitian ini adalah data primer dan data sekunder. Pengambilan sampel dilakukan dengan menggunakan metode snowball sampling. Sedangkan untuk mengetahui besarnya pengaruh variabel bebas $(X)$ terhadap variabel terikat $(Y)$ digunakan analisa Regresi Linear Berganda Berdasarkan hasil Uji Regresi Linear Berganda di peroleh persamaan: $Y=7,994+0,243 X_{1}+0,149 X_{2}+\varepsilon$. Kemudian secara simultan didapatkan bahwa kepercayaan dan kemudahan memiliki pengaruh terhadap keputusan pembelian berbelanja secara online. Sedangkan secara parsial baik itu variabel kepercayaan maupun variabel kemudahan memiliki pengaruh terhadap keputusan pembelian berbelanja secara online. Sedangkan kepercayaan dan kemudahan dapat mempengaruhi keputusan pembelian berbelanja secara online sebesar 18,4\%, sementara sisanya dipengaruhi oleh variabel lain yang tidak diteliti dalam penelitian ini. Disisi lain konsumen belumlah percaya sepenuhnya melakukan transaksi berbelanja pada toko online yang ada di website. Namun sebagian besar (80\%) mengatakan kemudahan mereka berbelanja pada toko online, seperti mudah dipelajari, mudah digunakan, mudah untuk dilakukan, dan mudah untuk memperoleh informasi produk.
\end{abstract}

Keywords: Keputusan Pembelian, Kepercayaan, Kemudahan

\section{A. PENDAHULUAN}

Pada zaman sekarang ini informasi sangat mudah diperoleh semenjak semakin meluasnya jaringan internet. Sehingga siapa saja mudah mengakses informasi yang mereka butuhkan dengan cukup bermodalkan smartphone, sehingga dunia seakan-akan berada dalam genggaman. Perkembangan teknologi informasi yang sangat cepat termasuk internet ternyata memberi dampak yang besar bagi seluruh aspek yang ada, tidak terkecuali perkembangan pada dunia bisnis. Dengan berkembangnya tekhnologi yang cepat membuat banyak orang menggunakan tekhnologi ini untuk melakukan transaksi jual beli menggunakan internet. Hal ini tidak aneh mengingat jumlah pengguna internet yang terus bertumbuh pesat dapat menjadi sebuah pasar yang potensial untuk dimasuki para pebisnis dan aktualisasi belanja yang terjadi sangat cepat, nyaman, serta dilakukan di mana saja dan kapan saja.

Pertumbuhan pengguna internet semakin pesat seiring semakin majunya teknologi. Dampak yang seperti itu juga berpengaruh dalam dunia usaha yang semakin marak di era globalisasi ini dan ketatnya persaingan bisnis. Dengan majunya teknologi internet juga dapat menjadi sarana dalam melakukan transaksi jual-beli. Pada masa sekarang ini internet bisa diakses di mana saja dan kapan saja. Hal ini dikarenakan banyaknya akses yang memungkinkan untuk menggunakan internet. Internet sudah menjadi kebiasaan yang membuat kita menjadi lebih maju dan modern. Akses yang mudah menjadi pendorong untuk menggunakan internet.

Menurut data dari sumber berupa web yang mencatat pengguna internet di dunia, jumlah pengguna internet, baik secara global maupun di Indonesia, terus meningkat tiap tahun. Berikut data dari www.internetworldstats.com mengenai pertumbuhan pengguna internet secara global maupun di Indonesia:

\section{Tabel 1 Pengguna Internet Di Indonesia}
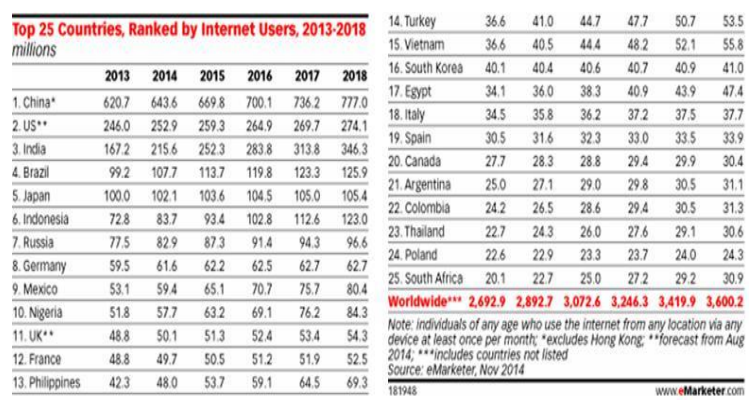

Sumber : http://www.emarketer.com

Berdasarkan tabel 1 di atas menunjukkan bahwa Negara Indonesia menduduki urutan keenam pengguna internet. Hal ini berarti terbuka peluang 
bagi pebisnis untuk melakukan penjualan melalui internet dengan menggunakan e-commerce berbasis aplikasi.

Semakin banyak e-commerce (layanan untuk sarana jual/beli online) yang berkembang di Indonesia membuat banyak perubahan pola belanja masyarakat yang awal bersifat konvensional kini berbelanja cukup dengan memilih produk yang ada di aplikasi online shooping.

Berikut ini merupakan urutan nama-nama situs belanja toko online yang berbasis aplikasi yang populer di Indonesia:

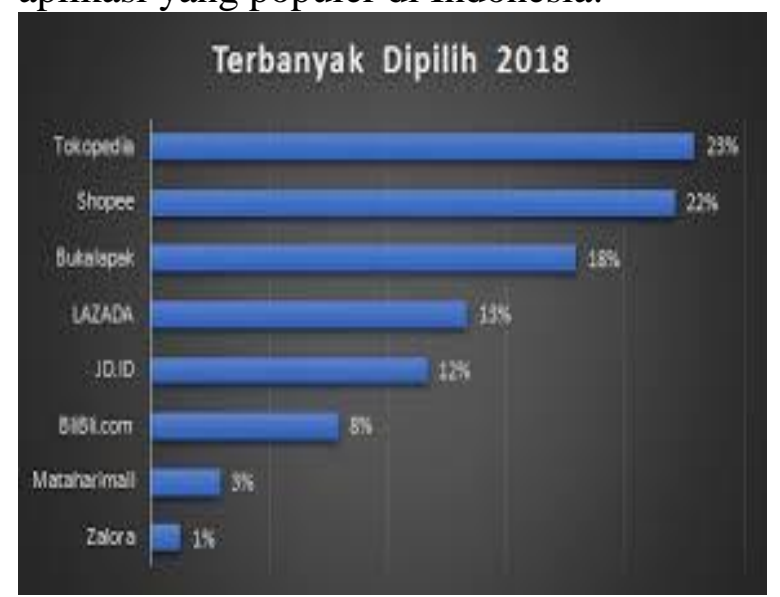

Gambar 1 Nama-Nama Toko Online di Indonesia

Sumber : http://www.kompasiana.com

Dari gambar 1 di atas terlihat bahwa meningkatnya jumlah transaksi online di Indonesia. Hal ini dapat membuat berbagai situs belanja online saling berkompetisi untuk merebut perhatian para calon konsumen di market virtual Indonesia. Selain itu, munculnya banyak pemain baru dengan konsep situs jual beli online di Indonesia membuat semarak bisnis ecommerce di Indonesia semakin bergairah.

Tak bisa dipungkiri, saat ini gaya belanja masyarakat Indonesia mulai beralih dari bertransaksi secara konvensional, kini masyarakat kita lebih suka belanja melalui online. Saat ini belanja online sedang booming, bahkan sudah menjadi pilihan alternatif bagi kebanyakan orang. Terutama bagi yang sangat sibuk dengan segala aktivitas dan rutinitas sehari-hari yang tidak bisa menyempatkan waktu mereka untuk melengkapi kebutuhannya. Begitu juga dikalangan mahasiswa yang sibuk dengan Eko dan Bisnis (Riau Economics and Business Reviewe) Volume 11, Nomor 3, 27 September 2020 aktivitas perkuliahannya, sehingga kurang memiliki waktu untuk berbelanja secara konvensional. Selain itu biasanya mahasiswa sebagai generasi muda sangat cepat mengikuti perkembangan dibidang teknologi informasi, sehingga mereka juga tidak ketinggalan memanfaatkan belanja pada toko online dalam pemenuhan kebutuhannya.

Kepercayaan konsumen dalam berbelanja online atau e-commerce adalah kendala yang sulit untuk dikendalikan karena ada hubungannya dengan niat beli konsumen. Mao (dalam Nusanrika 2015) mendefinisikan kepercayaan sebagai keyakinan suatu pihak akan menemukan apa yang diinginkan dari pihak lain bukan apa yang ditakutkan dari pihak lain dan kepercayaan merupakan keyakinan dari kedua pihak antara pembeli dan penjual dimana keduanya tidak akan memanfaatkan kelemahan pihak lain. Faktor kepercayaan merupakan faktor kunci dari sekian banyak faktor yang mempengaruhi terjadinya transaksi jual beli pada online shop. Hanya konsumen yang memiliki rasa kepercayaan penuh yang berani melakukan aktivitas jual beli melalui media online. Tanpa ada suatu kepercayaan penuh dari konsumen, sangatlah tidak mungkin transaksi melalui media online akan terjadi. Dalam sistem berbelanja online, ketika seorang konsumen ingin memutuskan untuk membeli produk secara online pastilah terbesit suatu keraguan akan terjadinya suatu resiko yang diterima oleh konsumen. Oleh karenanya kepercayaan sangat berperan penting dalam perdagangan melalui elektronik sejak bisnis internet diyakini oleh konsumen (Sonja \& Ewald, 2003). Hal yang ditakutkan itu seperti pengiriman barang yang dikuatirkan hilang dijalan, hal ini mengakibatkan konsumen membatalkan niatnya untuk melakukan transaksi pembelian secara online.

Selain itu dengan adanya online shop ini banyak kemudahan-kemudahan yang diperoleh oleh konsumen, seperti tidak habis waktu dan tenaga untuk pergi berbelanja, model pembayaran yang mudah.

P.ISSN: 1410-7988 E.ISSN: 2614-123X 
Hal yang tidak kalah penting adalah kemudahan yang dirasakan oleh konsumen dalam mengunakan aplikasi pada toko online ini.

Dari pra survei yang dilakukan penulis ternyata ada mahasiswa yang pernah berbelanja secara online pada website yang berbasis aplikasi dan ada juga yang belum pernah melakukan transaksi. Namun baik bagi yang pernah atau yang belum pernah bertransaksi sama-sama merasakan ada keraguan dalam hati menyangkut hal apakah toko online yang dituju dapat dipercaya atau tidak. Selain itu bagi yang belum pernah melakukan transaksi juga merasa binggung untuk tahap awal bagaimana caranya mengunakan aplikasi-aplikasi online shopping yang ada.

Berdasarkan uraian di atas, maka peneliti tertarik untuk meneliti dengan judul "Pengaruh Kepercayaan Dan Kemudahan Terhadap Keputusan Pembelian Belanja Secara Online (Studi Kasus Pada Konsumen Belanja Online Di Prodi Manajemen Perusahaan Fekonsos Uin Suska Riau).

\section{Belanja Online \\ Defenisi Belanja Online}

Belanja online adalah proses dimana konsumen membeli produk atau jasa di internet (http://en.wikipedia.org/). Belanja online / perdagangan elektronik (Electronic commerce atau e-commerce) adalah penyebaran, pembelian, penjualan, pemasaran barang dan jasa melalui sistem elektronik seperti internet atau televisi, world wide web atau jaringan komputer lainnya. Ecommerce dapat melibatkan transfer dana elektronik, pertukaran data elektronik, sistem manajemen inventori otomatis, dan sistem pengumpulan data otomatis. Pengertian Electronic Commerce (EC) juga dapat didefinisikan konsep baru yang bisa digambarkan sebagai proses jual beli barang atau jasa pada World Wide Web (Suyanto, 2003:11). Turban et al., (2000) seperti dikutip Suyanto (2003:11) mendefinisikan belanja online sebagai proses jual beli produk, jasa dan informasi melalui jaringan informasi termasuk internet.

Eko dan Bisnis (Riau Economics and Business Reviewe) Volume 11, Nomor 3, 27 September 2020
Menurut Cowles et al., (2002) seperti dikutip Handayani (2010:11) ada tiga elemen berbeda yang ditemui di $e$ commerce yaitu:

a. Vendor yakni organisasi atau orang yang menjual barang atau jasa secara elektronik. Mereka disebut electronic vendor atau $e$-vendor.

b. Konsumen yang menggunakan jasa elektronik untuk mencari informasi, memesan jasa atau membeli produk.

c. Teknologi berupa perangkat keras (komputer, internet, telepon seluler), perangkat lunak yang dapat digunakan untuk bertransaksi.

\section{Karakteristik Website}

Karakteristik website didefinisikan sebagai atribut yang dipertimbangkan konsumen dalam melakukan penilaian pada website suatu toko online.

Karakteristik website diukur menggunakan lima dimensi yaitu (Rahadi, 2013:2):

a. Kenyamanan belanja. Dalam berbelanja melalui media online, konsumen mengharapkan bahwa proses pembelanjaan atau pembelian akan memperoleh kemudahan. Kemudahan tersebut akan menyebabkan konsumen merasa nyaman dengan penggunaan suatu situs atau web dari toko online tertentu. Kenyamanan konsumen dalam berbelanja melalui media online dapat diukur dengan indikator berikut:

1) Merasa nyaman saat berbelanja di bisnis online. Dalam berbelanja, konsumen berharap dapat berbelanja dengan caranya sendiri. Dengan berbelanja melalui media online, konsumen dapat memilih produk sesuai dengan keinginan dan kebutuhannya tanpa harus terbatas oleh waktu.

2) Dapat menghemat waktu dengan berbelanja melalui media online. Konsumen dewasa ini memiliki aktivtas yang tinggi. Kondisi ini menyebabkan konsumen tidak memiliki banyak waktu luang untuk

P.ISSN: 1410-7988 E.ISSN: 2614-123X 
berbelanja. Dengan berbelanja secara online, konsumen dapat melakukan penghematan waktu.

3) Bisnis online memiliki prosedur pemesanan yang mudah. Untuk meningkatkan kenyamanan konsumen dalam berbelanja, pihak manajemen harus menciptakan prosedur pemesanan atau pembelian yang mudah.

4) Berbelanja di bisnis online tidak memerlukan banyak bantuan dari orang lain atau perusahaan. Tata cara pemesanan produk yang detail dan mudah untuk dipahami menyebabkan konsumen merasa nyaman karena tidak mengalami kesulitan dalam memesan atau membeli produk hingga konsumen tidak membutuhkan petunjuk dari orang lain atau perusahaan yang bersangkutan.

5) Cara mengakses website bisnis online mudah untuk dipelajari. Kemudahan untuk mencari atau mengakses suatu situs memberikan suatu kenyamanan bagi konsumen khususnya untuk mencari produk yang dibutuhkan. Oleh sebab itu, penting bagi sebuah bisnis online untuk mudah diakses konsumen.

6) Sistem yang digunakan pada bisnis online sederhana. Sistem pemesanan dan transaksi pembelian yang mudah dan sederhana memberikan kontribusi pada kenyamanan konsumen berbelanja di bisnis online.

7) Dapat membeli produk secara eceran di bisnis online. Kesediaan suatu bisnis online untuk melayani konsumen yang membeli suatu produk dalam jumlah yang sedikit (kecil) akan membuat konsumen merasa nyaman berbelanja pada suatu bisnis online.

b. Desain situs. Situs dengan desain yang menarik akan lebih disukai konsumen. Hal ini menunjukkan bahwa perusahaan harus mampu mendesain website perusahaan dengan lebih menarik.
Desain situs dapat diukur dengan indikator berikut:

1) Desain website bisnis online menarik secara visual. Salah satu daya tarik suatu website adalah tingkat kemenarikan secara visual. Semakin menarik suatu website akan semakin tinggi kemungkinannya untuk dikunjungi konsumen.

2) Bisnis online memiliki banyak pilihan produk yang dijual. Konsumen mengharapkan dapat membeli berbagai macam kebutuhannya dari sebuah toko termasuk toko yang ada dalam bisnis online. Hal ini menunjukkan bahwa, suatu toko online yang memiliki banyak produk yang dijual akan semakin diminati konsumen.

3) Website dari bisnis online memiliki penampilan yang profesional. Salah satu bentuk kepercayaan konsumen pada bisnis online jika bisnis online tersebut memiliki penampilan yang profesional karena akan memberikan image positif bagi konsumen terhadap suatu bisnis online.

4) Cepat dan mudah dalam transaksi di bisnis online. Salah satu persayaratan transaksi pembelian dewasa ini adalah cepat dan mudah. Kemudahan dan kecepatan transaksi pembelian di suatu bisnis online akan memberikan kontribusi pada tingginya minat konsumen untuk berbelanja pada suatu bisnis online.

5) Desain website bisnis online mudah untuk dipahami. Desain suatu website bisnis online harus mudah untuk dipahami yaitu memiliki tampilan visual yang menggambarkan produk atau jasa layanan yang dijual. Semakin mudah suatu website untuk dipahami konsumen akan memberikan kontribusi pada kepuasan dan kepercayaan konsumen pada suatu bisnis online. 
6) Bisnis online menampilkan produk dengan jelas. Minat konsumen untuk membeli suatu produk akan semakin besar jika dapat melihat tampilan visual dari produk yang dijual. Hal ini menunjukkan bahwa kemampuan suatu bisnis online untuk menampilkan produk dengan jelas akan memberikan kontribusi pada pengambilan keputusan pembelian konsumen.

7) Bisnis online memiliki desain website yang konsisten. Perubahan desain suatu situs / website merupakan suatu hal yang wajar. Namun perlu dipahami bahwa perubahan suatu desain website yang ekstrim akan membingungkan konsumen.

c. Informatif. Informasi yang disajikan salam suatu website harus mampu memberikan informasi secara detail tentang produk yang dijual, cara pemakaian, dan lain sebagainya. Dimensi informatif dapat diukur dengan indikator berikut:

1) Bisnis online menyediakan informasi yang banyak. Semakin banyak informasi mengenai produk yang dijual oleh suatu bisnis online akan memberikan kemudahan bagi konsumen untuk mengetahui karakteristik dari produk yang dijual.

2) Bisnis online menyediakan informasi yang akurat. Konsumen mengharapkan dapat memperoleh informasi yang akurat dari suatu produk yang dijual oleh suatu bisnis online sebelum mengambil keputusan pembelian mereka.

3) Bisnis online menyediakan beragam informasi (pembayaran, pengiriman). Cara pembayaran dan pengiriman barang merupakan salah satu faktor penting yang memberikan kontribusi pada pengambilan keputusan pembelian konsumen.

4) Bisnis online menyediakan informasi dengan baik. Suatu bisnis online yang baik harus mampu menyediakan informasi mengenai segala macam hal

Eko dan Bisnis (Riau Economics and Business Reviewe) Volume 11, Nomor 3, 27 September 2020 (produk, harga, cara pembayaran, pengiriman, dan lain-lain) dengan lengkap.

5) Bisnis online menyediakan informasi yang bermanfaat. Informasi yang disediakan pihak manajemen bisnis online dilakukan dengan tujuan untuk memberikan manfaat lebih bagi calon konsumen.

d. Keamanan. Pada saat melakukan pembelian melalui media online, ada beberapa data konsumen yang diketahui oleh penjual. Oleh sebab itu, penjual diharuskan dapat menjaga kerahasiaan identitas pembeli. Selain itu, pihak penjual juga harus memberikan jaminan bahwa transaksi pembelian berlangsung secara aman. Dimensi keamanan dapat diukur dengan indikator berikut:

1) Merasa aman dalam transaksi dengan bisnis online. Dewasa ini banyak perusahaan yang melanggar etika dalam berbisnis. Konsumen lebih mengutamakan berbisnis dengan bisnis online yang mampu menjamin keamanan transaksi.

2) Bisnis online menjaga privasi konsumen dalam transaksi. Banyak informasi pribadi konsumen yang dapat diakses melalui media online. Suatu bisnis harus dapat menjaga privasi konsumennya.

3) Bisnis online tidak menyalahgunakan informasi pribadi konsumen. Bisnis yang beretika adalah kemampuan salah satu pihak (bisnis online) untuk tidak menyalahgunakan informasi konsumen.

4) Bisnis online tidak memberikan informasi konsumen ke situs lain tanpa izin. Kecanggihan teknologi informasi menyebabkan tingginya penyebaran informasi data diri konsumen di dunia maya. Suatu bisnis online tidak dapat sewenangwenang menyebarkan informasi konsumen ke situs yang lainnya.

5) Bisnis online mencegah kebocoran informasi kartu kredit pelanggan.

P.ISSN: 1410-7988 E.ISSN: 2614-123X 
Transaksi dalam bisnis online biasanya dilakukan dengan menggunakan kartu kredit. Pihak manajemen bisnis online harus dapat mencegah kebocoran informasi kartu kredit konsumen.

6) Bisnis online ini mencegah kebocoran e-mail pelanggan. Pihak pemasar harus menjaga kerahasian konsumen salah satunya adalah tidak memberikan informasi alamat e-mail konsumen pada pihak lain.

7) Bisnis online menjaga keakurasian transaksi pembayaran. Tagihan yang harus dibayar konsumen harus sesuai dengan produk yang dibelinya. Oleh sebab itu, keakuratan transaksi pembayaran merupakan salah satu syarat mutlak untuk dipenuhi.

e. Komunikasi. Dalam proses pembelian, konsumen terkadang membutuhkan informasi secara langsung dengan penjual. Berdasarkan hal tersebut maka alamat atau nomor telepon penjual sebaiknya mudah untuk dihubungi. Dimensi komunikasi dapat diukur dengan indikator berikut:

1) Konsumen bebas untuk berbicara tentang ide atau keluhan dengan bisnis online. Masukan dari konsumen pada dasarnya merupakan salah satu cara untuk membangun perusahaan menjadi lebih baik. Berdasarkan hal tersebut maka penting bagi pihak manajemen bisnis online untuk mau menerima ide atau masukan dari konsumen.

2) Bisnis online memiliki sistem Frequently Asked Question (FAQ) yang baik. Konsumen mengharapkan memperoleh jawaban atas pertanyaan mereka pada suatu binsis online. Semakin banyak frekuensi jawaban dari pihak manajemen bisnis online semakin baik kualitas komunikasi yang dijalin dengan konsumen.

3) Pelanggan aktif dapat meninjau produk yang dijual di bisnis online. Suatu bisnis online yang baik harus mampu memberikan atau menyampaikan produk-produk baru yang dijualnya. Hal ini akan menjadi efektif saat konsumen juga rajin melihat produkproduk yang ditawarkan.

4) Bisnis online memberikan kebebasan bertukar pendapat antara pelanggan. Dalam bisnis online, konsumen dapat pula berinterkasi dengan konsumen lain. Kemudahan konsumen untuk berinteraksi dengan konsumen lain akan memberikan kontribusi pada kepercayaan konsumen pada suatu bisnis online.

5) Bisnis online menyediakan e-mail dan alamat perusahaan dengan jelas. Untuk menyampaikan keluhan maupun saran pihak manajemen bisnis online sebaiknya memberikan sarana seperti alamat e-mail dan alamat perusahaan yang jelas.

\section{Kepercayaan Konsumen Defenisi Kepercayaan Konsumen}

Kepercayaan menurut Balester et al., (2000) seperti dikutip Ferrinadewi (2005:1) merupakan variabel kunci dalam mengembangkan keinginan konsumen akan produk yang tahan lama (durable) untuk mempertahankan hubungan jangka panjang, dalam hal ini hubungan konsumen dengan merek dari suatu perusahaan tertentu. Hal ini bertujuan untuk mendapatkan kepercayaan dari konsumen pada produk perusahaan.

Berdasarkan pendapat tersebut konsumen perlu mengalami sendiri dalam proses pertukaran sehingga dapat terbentuk rasa percaya terhadap merek dalam benak konsumen yang didefinisikan sebagai keterlibatan. Melalui keterlibatan konsumen ini akan tercipta pengalaman yang menjadi awal terbentuknya kepercayaan. Kepercayaan konsumen pada suatu produk dapat diciptakan dengan memberikan / menyampaikan produk sesuai dengan spesifikasi yang diiklankan dalam website perusahaan. Saat konsumen menerima barang atau jasa yang sesuai dengan iklan perusahaan di website, maka akan menumbuhkan rasa percaya konsumen pada perusahaan.

\footnotetext{
P.ISSN: $1410-7988 \quad$ E.ISSN: 2614-123X
} 
Kepercayaan konsumen dapat pula diciptakan dengan kejujuran produsen atau pemasar dalam menyampaikan karakteristik produk atau jasa layanan yang dijual dengan detail kepada konsumen. Selain itu, pemberian jaminan atau garansi dari perusahaan atau pemasar (seperti: penukaran atau penggantian barang karena rusak, servis atas produk yang rusak pasca pemakaian) kepada konsumen, pasca pembelian produk juga akan memberikan kontribusi pada tingkat kepercayaan konsumen.

Menurut Costabile (1998) seperti dikutip Ferrinadewi (2005:4) mendefinisikan kepercayaan konsumen sebagai "persepsi akan keterhandalan dari sudut pandang konsumen yang didasarkan pada pengalaman atau lebih pada urut-urutan transaksi atau interaksi yang dicirikan oleh terpenuhinya harapan akan kinerja produk dan kepuasan".

Mempertimbangkan hal tersebut, kepercayaan merek memiliki peranan yang penting bagi produk. Apabila efek dari kepercayaan merek tidak dikendalikan dapat mengakibatkan pertimbangan akan tingkat kepuasan pelanggan yang berlebihan dalam mengembangkan komitmen konsumen terhadap produk.

Morgan dan Hunt seperti dikutip Ferrinadewi (2005:4) menyatakan bahwa trust (kepercayaan) adalah variabel kunci dalam mengembangkan keinginan yang tahan lama untuk terus mempertahankan hubungan jangka panjang suatu merek tertentu. Costabile (1998) seperti dikutip Ferrinadewi (2005:4) menyatakan bahwa, proses terciptanya kepercayaan terhadap merek didasarkan pada pengalaman mereka dengan merek tersebut. Pengalaman menjadi sumber bagi konsumen untuk terciptanya rasa percaya pada merek. Pengalaman ini akan mempengaruhi evaluasi konsumen dalam konsumsi, penggunaan atau kepuasan secara langsung dan kontak tidak langsung dengan merek.

\section{Komponen Kepercayaan Konsumen}

Balester et al., (2000) seperti dikutip Ferrinadewi (2005:4) menyatakan bahwa kepercayaan merek merefleksikan dua komponen yaitu:

a. Brand reliability. Brand reliability bersumber dari keyakinan konsumen bahwa produk tersebut mampu memenuhi nilai yang dijanjikan. Dengan kata lain, konsumen yakin bahwa merek yang bersangkutan mampu memenuhi dan memberikan kepuasan bagi mereka.

b. Brand intention. Brand intention didasarkan pada keyakinan konsumen bahwa brand tersebut akan mampu mempertahankan kepentingan konsumen ketika masalah dalam konsumsi produk muncul secara tidak terduga.

\section{Pengukuran Kepercayaan Konsumen}

Ada banyak indikator yang dapat digunaan untuk mengukur tingkat kepercayaan konsumen. Rahadi (2013:5) mengukur tingkat kepercayaan konsumen dengan indikator sebagai berikut:

a. Percaya pada informasi yang disampaikan bisnis online. Informasi yang detail dan akurat memberikan kontribusi pada tingkat kepercayaan konsumen.

b. Percaya pada janji bisnis online. Kemampuan suatu bisnis online untuk menepati janji yang diberikan kepada konsumen memberikan kontribusi positif pada tingkat kepuasan konsumen.

c. Percaya pada produk yang dijual bisnis online. Produk yang diiklankan pada suatu website perusahaan haruslah sama dengan produk yang dikirimkan kepada konsumen. Jika produk yang dikirimkan sesuai dengan produk yang diiklankan, konsumen akan percaya pada suatu bisnis online.

d. Percaya pada pengiriman produk yang dilakukan oleh bisnis online. Pihak manajemen bisnis online harus dapat menepati janji dalam bentuk waktu penyampaian produk yang dibeli konsumen. 
e. Akan terus bertransaksi dengan bisnis online. Salah satu bentuk kepercayaan konsumen pada suatu bisnis online ditunjukkan oleh kesediaan konsumen membeli kembali produk perusahaan di masa yang akan datang.

\section{Kemudahan Transaksi}

Hal yang menjadi pertimbangan selanjutnya bagi pembeli online adalah faktor kemudahan transaksi. Faktor kemudahan ini terkait dengan bagaimana operasional bertransaksi secara online. Biasanya calon pembeli akan mengalami kesulitan pada saat pertama kali bertransaksi online, dan cenderung mengurungkan niatnya karena faktor keamanan serta tidak tahu cara bertransaksi online.

Dilain pihak, ada juga calon pembeli yang berinisiatif untuk mencoba karena telah mendapatkan informasi tentang cara bertransaksi online. Suatu website online shopping yang baik adalah yang menyediakan petunjuk cara bertransaksi online, mulai dari cara pembayaran, dan fitur pengisian form pembelian.

Davis (1989) mendefinisikan kemudahan (ease of use) sebagai suatu tingkatan dimana seseorang percaya bahwa suatu teknologi dapat dengan mudah digunakan. Menurut Goodwin (1987) dalam Adam, et al. (1992), intensitas penggunaan dan interaksi antara user dengan sistem juga dapat menunjukkan kemudahan. Suatu sistem online yang lebih sering digunakan menunjukkan bahwa sistem tersebut lebih dikenal, lebih mudah dioperasikan dan lebih mudah digunakan oleh user.

Berdasarkan definisi di atas dapat disimpulkan bahwa kemudahan akan mengurangi usaha (baik waktu dan tenaga) seseorang di dalam mempelajari sistem online. Jika dianalogikan pada sistem berbelanja online (online shopping), kemudahan dapat diindikasikan bahwa pembeli yang memiliki pengetahuan tentang online shopping tidak mengalami kesulitan ketika berbelanja online dibandingkan pembeli yang tidak memiliki pengetahuan tersebut. Pembeli online percaya bahwa Volume 11, Nomor 3, 27 September 2020 website online shopping yang lebih fleksibel, mudah dipahami dan mudah pengoperasiannya (compartible) sebagai karakteristik kemudahan.

\section{Pengaruh Kepercayaan (Trust) Terhadap Keputusan Pembelian}

Pihak penjual harus menganut kepuasan pelanggan (costumer satisfaction) supaya dapat memepertahankan hubungan jangka panjang dengan para pembelinya. Agar dapat bertahan hidup didalam era berbelanja online.

Seiring dengan maraknya kejahatan internet yang sering terjadi akhir-akhir ini seperti penipuan, pembobolan kartu kredit, dan kejahatan-kejahatan lain di dunia maya, kepercayaan (trust) menjadi salah satu faktor yang sangat penting saat melakukan transaksi berbelanja online.

Didalam konsep ini kepercayaan memiliki arti bahwa pembeli percaya terhadap kemampuan penjual online apakah penjual online dapat menjamin keamanan ketika pembeli melakukan transaksi online. Keamanan sendiri memiliki arti bahwa transaksi penjual online mampu dipercaya. Semakin populer website berbelanja online tersebut maka tingkat kepercayaan pembeli kepada website belanja online tersebut semakin tinggi. Pembelipun akan semakin yakin dan percaya terhadap keandalan website.

Selanjutnya adalah, kepercayaan pembeli terhadap penjual online yang terkait bagaimana si penjual tersebut dengan keahliannya dapat meyakinkan pembeli menjamin keamanan ketika sedang melakukan transaksi pembayaran meyakinkan transaksi akan segera diproses. Keahlian ini terkait dengan keberadaan penjual online. Teknologi yang semakin berkembang, begitu pula modus penipuan yang berbasis teknologi pada belanja online juga ikut berkembang. Tidak sedikit pula penjual online fiktif yang menjual dan memasarkan produk yang fiktif pada situssitus belanja online.

Kepercayaan adalah mental atau verbal pernyataan yang mencerminkan

P.ISSN: 1410-7988 E.ISSN: 2614-123X 
pengetahuan khusus seseorang dan penilaian tentang beberapa ide atau hal (Sciffman dan Kanuk, 2000). Setiap konsumen memiliki tingkat kepercayaan yang berbeda ada yang memiliki tingkat kepercayaan lebih tinggi dan ada pula yang memiliki tingkat kepercayaan yang lebih rendah. Hal tersebut disebabkan oleh kepercayaan konsumen menyangkut kepercayaan bahwa suatu produk memiliki berbagai atribut dan manfaat dari berbagai atribut tersebut. Kepercayaan konsumen terhadap suatu produk, atribut dan manfaat produk menggambarkan persepsi konsumen.

Bertransaksi secara online memiliki kepastian dan informasi yang tidak simetris. Oleh sebab itu harus ada rasa saling percaya antara penjual dan pembeli (Gefen, 2002), terdapat banyak makalah yang menunjukkan bahwa kepercayaan konsumen akan $e$ commerce merupakan salah satu faktor kunci. Koufaris dan Hampton-Sosa (2004) mendefinisikan kepercayaan awal, dan selanjutnya mengasumsikan bahwa apabila seorang konsumen menjalin suatu hubungan dan jaringan kerja yang baik pada toko offline, dapat meningkatkan percaya diri pada toko online.

Kaufaris dan Hamton-Sosa (2004) mempelajari bagaimana pengalaman pada situs web dapat mempengaruhi kepercayaan konsumen pada perusahaan itu sendiri melalui kepercayaan pada situs web. Ketika melakukan kegiatan belanja secara online konsumen banyak diberikan kebebasan dan kontrol karena mereka bebas mengakses dan memungkinkan pembeli untuk membandingkan produk dan harga (Wolfinbarger dan Gilly, 2000).

Koufaris dan Hampton-Sosa (2004) membuktikan bahwa ada hubungan positif antara kontrol, manfaat, dan kemudahan yang dirasakan dalam menggunakan situs web. Jika ada perusahaan yang situs webnya mudah digunakan, bermanfaat, dan aman ketika digunakan konsumen cenderung akan melakukan pembelian pada situs web tersebut. Oleh karena itu jika konsumen mendapatkan pengalaman yang baik saat bertransaksi secara online dan merasa yakin Volume 11, Nomor 3, 27 September 2020 akan keamanannya ketika melakukan transaksi online ataupun belanja online di sebuah situs online, maka konsumen cenderung untuk melakukan keputusan pembelian yang lebih tinggi pada situs belanja online tersebut. Berdasarkan kepercayaan dan pengalaman mereka sebelumnya pada toko online, mereka akan lebih suka merekomendasikan toko online kepada orang lain, dibandingkan dengan mereka yang kurang percaya diri dalam berbelanja di toko online.

Terdapat beberapa saran yang dianjurkan sebelum pembeli melakukan pembelian secara online terkait dengan masalah kepercayaan (wikipedia.com, dalam adityo, 2010), yaitu:

a. Setia pada penjual yang dikenal.

b. Bertanya kepada konsumen "independen atau lainnya" tentang pengalaman belanja online mereka.

c. Memastikan bahwa terdapat informasi kontak menyeluruh tentang produk pada website.

d. Memastikan bahwa penjual online telah memiliki trust mark atau trust seal.

e. Memastikan bahwa penjual online menyatakan secara tegas bahwa terdapat kebijakan kerahasiaan (privacy policy). Seperti misalnya: penjual online menyatakan bahwa tidak akan memberikan informasi pribadi pembeli kepada pihak lain tanpa persetujuan dari pihak pembeli.

f. Memastikan bahwa website belanja online memiliki fasilitas penjamin keamanan dan kerahasiaan kartu kredit seperti Secure Sockets Layer (SSL). SSL ini berfungsi untuk mencegah pencurian informasi kartu kredit oleh hacker. Menurut Jia, Shen (undated) terdapat beberapa konstruk yang merupakan indikator kepercayaan (Trust) yaitu: (1) sistem keamanan website; (2) sistem kerahasiaan website; (3) jaminan keamanan dan kerahasiaan; (4) kompensasi kerugian karena alasan keamanan dan kerahasian.

P.ISSN: 1410-7988 E.ISSN: 2614-123X 


\section{Pengaruh Kemudahan (Ease of Use) Terhadap Keputusan Pembelian}

Davis et al. (1989) mendefinisikan percieved ease of use sebagai keyakinan akan kemudahan penggunaan, yaitu tingkatan dimana user percaya bahwa teknologi/sistem tersebut dapat digunakan dengan mudah dan bebas dari masalah. Intensitas penggunaan dan interaksi antara pengguna dengan sistem juga dapat menunjukkan kemudahan penggunaan. Davis et al. (1989) mendefinisikan perceived usefulness sebagai keyakinan akan kemanfaatan, yaitu tingkatan dimana user percaya bahwa penggunaan teknologi/sistem akan meningkatkan performa mereka dalam bekerja. Thompson et al. (1991) juga menyebutkan bahwa individu akan menggunakan teknologi informasi jika mengetahui manfaat positif atas penggunaannya. Davis et al. (1989) memberikan beberapa indikator percieved ease of use: ease of learn, controllable, clear and understandable, flexible, ease to become skillful, ease to use. Terdapat beberapa indikator lain yang dikemukakan oleh Davis et al. (1989) diantaranya adalah sebagai berikut: 1) Teknologi informasi (TI) sangat mudah dipelajari; 2) Teknologi informasi mengerjakan dengan mudah apa yang diinginkan oleh pengguna; 3) Keterampilan pengguna akan bertambah dengan menggunakan Teknologi informasi; 4) TI sangat mudah untuk dioperasikan.

Definisi usage intention menurut Davis et al. (1989) adalah kecenderungan perilaku untuk tetap menggunakan suatu teknologi dan keinginan untuk memotivasi pengguna lain. Dari penelitian penggunaan internet Gefen et al. (2003) mendefinisikan usage intention adalah niat penggunaan kembali terutama ditujukan pada individu untuk melakukan pembelian secara online melalui internet. Niat untuk selalu menggunakan online dalam pembelian dan merekomendasikan pembelian online (Cheng et al., 2004).

Menurut Goodwin (1987); Silver (1988); dalam Adityo, (2010), intensitas penggunaan dan interaksi antara user dengan sistem juga dapat menunjukkan kemudahan.

Eko dan Bisnis (Riau Economics and Business Reviewe) Volume 11, Nomor 3, 27 September 2020
Suatu sistem online yang lebih sering digunakan menunjukkan bahwa 47 sistem tersebut lebih dikenal, lebih mudah dioperasikan dan lebih mudah digunakan oleh user. Beberapa penelitian terdahulu menunjukkan bahwa kemudahaan (ease of use) merupakan faktor utama yang berpengaruh terhadap penggunaan online shopping (Davis, 1989; Venkatesh dan Davis, 2000; Pikkarainen, et al., 2004).

Berdasarkan definisi dan teori yang dikemukakan diatas kemudahan berpengaruh pada keputusan konsumen untuk melakukan pembelian secara online. Kemudahan dalam menggunakan dan mengoperasikan teknologi internet untuk melakukan kegiatan belanja online menjadiakan konsumen untuk memutuskan pembelian secara online. Sebuah website tidak harus selalu menarik secara teknis saja tetapi juga harus mudah digunakan agar memberi dorongan positif bagi keputusan konsumen untuk melakukan transaksi kepada perusahaan. Kemudahan penggunaan teknologi internet untuk melakukan pembelian online dapat digunakan perusahaan untuk menjaring kelompok pelanggan yang memberi keuntungan besar bagi perusahaan.

Beberapa penelitian terdahulu tentang kepercayaan (Gefen, Karahanna, Straub, 2003) menunjukkan hasil bahwa kepercayaan berpengaruh positif terhadap keputusan pembelian website.

\section{Keputusan Pembelian \\ Pengertian Keputusan Pembelian}

Pada dasarnya keputusan pembelian ialah suatu tindakan atau perilaku konsumen jadi atau tidaknya melakukan suatu pembelian atau transaksi, banyak tidaknya jumlah konsumen dalam mengambil keputusan menjadi salah satu penentu tercapai atau tidaknya tujuan perusahaan. Konsumen sering dihadapkan dengan beberapa pilihan dalam menggunakan suatu produk. Hal tersebut menyebabkan konsumen harus mempertimbangkan baik-baik sebelum mengambil keputusan untuk membeli.

P.ISSN: 1410-7988 E.ISSN: 2614-123X 
Menurut Kotler dan Amstrong (2008: 227) mengemukakan bahwa keputusan pembelian adalah tahap proses keputusan dimana konsumen secara aktual melakukan pembelian produk.

Keputusan, menurut Follet (dalam Hasan, 2002: 9), merupakan hasil dari pemecahan masalah yang dihadapinya dengan tegas. Suatu keputusan merupakan jawaban yang pasti terhadap suatu pertanyaan. Keputusan harus mampu memberikan jawaban pertanyaan tentang apa yang dibicarakan dalam hubungannya dengan perencanaan.

Sedangkan pengertian pengambilan keputusan menurut Terry (dalam Hasan, 2002: 12) adalah pemilihan alternatif perilaku (kelakuan) tertentu dari dua atau lebih alternatif yang ada. Pengambilan keputusan terjadi saat seseorang dihadapkan pada beberapa pilihan dan dia harus memilih salah satu yang paling tepat untuk memenuhi keinginan dan kebutuhannya. Secara sederhana pengambilan keputusan adalah proses yang digunakan untuk memilih suatu tindakan sebagai cara pemecahan suatu masalah (Stoner, dalam Hasan, 2002: 13).

\section{Proses Keputusan Pembelian}

Menurut Kotler dan Armstrong (2008: 224) proses pengambilan keputusan pembelian terdiri dari lima tahap: pengenalan kebutuhan, pencarian informasi, pengevaluasian alternatif, keputusan pembelian, dan perilaku setelah pembelian. Dengan demikian keputusan pembelian dapat menjadi ukuran tercapai atau tidaknya tujuan suatu perusahaan.

1) Pengenalan kebutuhan (need recognition). Pengenalan kebutuhan merupakan tahap pertama proses keputusan pembelian dimana konsumen mengenali permasalahan atau kebutuhan. Pembeli merasakan adanya perbedaan antara keadaan aktual dan sejumlah keadaan yang diinginkan. Kebutuhan itu dapat dipicu oleh stimulan internal ketika salah satu kebutuhan normal lapar, haus, seks naik ke tingkat yang cukup tinggi sehingga menjadi

Eko dan Bisnis (Riau Economics and Business Reviewe) Volume 11, Nomor 3, 27 September 2020 pendorong. Selain itu pula kebutuhan juga dipicu oleh rangsangan eksternal.

2) Pencarian Informasi. Pencarian informasi merupakan tahap proses pengambilan keputusan pembeli dimana konsumen tergerak untuk mencari informasi tambahan, konsumen mungkin sekedar meningkatkan perhatian atau mungkin pula mencari informasi secara aktif. Konsumen dapat memperoleh informasi dari berbagai sumber. Sumber itu meliputi:

a) Sumber pribadi (keluarga, teman, tetangga, rekan kerja).

b) Sumber komersial (iklan, penjualan, pengecer, bungkus, situs web, dan lain-lain).

c) Sumber publik (media masa, organisasi pemberi peringkat).

d) Sumber berdasarkan pengalaman (memegang, meneliti, menggunakan produk).

3) Pengevaluasian Alternatif. Pengevaluasian alternatif merupakan tahap proses keputusan pembeli dimana konsumen menggunakan informasi untuk mengevaluasi berbagai merek alternatif di dalam serangkaian pilihan. Cara konsumen memulai usaha mengevaluasi alternatif pembelian tergantung pada konsumen individual dan situas pembelian tertentu. Dalam beberapa kasus, konsumen menggunakan kalkulasi yang cermat dan pikiran yang logis. Dalam waktu yang lain, konsumen bersangkutan mengerjakan sedikit atau tidak mengerjakan evaluasi sama sekali; melainkan mereka membeli secara impulsif atau bergantung pada intuisi.

4) Menentukan Pembelian. Menentukan pembelian merupakan tahap proses keputusan dimana konsumen secara aktual melakukan pembelian produk. Secara umum, keputusan pembelian konsumen akan membeli merek yang paling disukai, tetapi ada dua faktor yang muncul diantara kecenderungan pembelian dan keputusan pembelian.

P.ISSN: 1410-7988 E.ISSN: 2614-123X 
Faktor pertama adalah sikap orang lain, karena konsumen mungkin membentuk kecenderungan pembelian berdasar pada pendapat yang diharapkan. Faktor kedua adalah faktor situasi yang tak terduga, karena keadaan tak terduga dapat mengubah kecenderungan pembelian. Dalam keputusan membeli konsumen seringkali ada lebih dari dua pihak yang terlibat dalam proses pembelian. Umumnya ada lima peran yang dapat dilakukan seorang konsumen. Ada kalanya kelima peran ini dipegang oleh satu orang, namun sering kali pula peranan tersebut dilakukan oleh beberapa orang.

Menurut Kotler (2000: 159) kelima peranan tersebut meliputi :

a) Pemprakarsa (initiator), yaitu orang yang pertama kali menyadari adanya keinginan atau kebutuhan yang belum terpenuhi dan mengusulkan ide untuk membeli suatu barang atau jasa tertentu.

b) Pemberi Pengaruh (influencer), yaitu orang yang pandangan, nasihat atau pendapatannya mempengaruhi keputusan pembelian.

c) Pengambilan Keputusan (decider), yaitu orang yang mengambil keputusan pembelian.

d) Pembeli (buyer), yaitu orang yang melakukan pembelian.

e) Pemakai (user), yaitu orang yang mengkonsumsi atau menggunakan barang atau jasa yang dibeli.

Perilaku Setelah Pembelian

Perilaku setelah pembelian merupakan tahap proses keputusan pembeli konsumen melakukan tindakan lebih lanjut setelah pembelian berdasarkan pada kepuasan atau ketidakpuasan mereka. Menurut Kotler dan Amstrong (2008: 228) yang menentukan puas tidak pusanya pembelian terletak pada hubungan antara harapan konsumen dan kinerja produk yang dirasakan. Jika produk jauh di bawah harapan konsumen, maka konsumen kecewa; jika produk memenuhi harapannya, konsumen terpuaskan; jika melebihi harapannya, maka konsumen akan sangat puas.

\section{Pembuatan Keputusan Pembelian}

Menurut Sutisna (2003: 11) terdapat dua keterlibatan konsumen dalam pembuatan keputusan pembelian yang meliputi:

1) Keterlibatan situasional. Keterlibatan situasional hanya terjadi seketika pada situasi tertentu dan bersifat temporer. Misal adanya kebutuhan pakaian baru menjelang hari lebaran.

2) Keterlibatan Tahan Lama. Keterlibatan tahan lama berlangsung lebih lama dan bersifat permanen. Seorang konsumen membeli barang dengan keterlibatan yang permanen karena menganggap bahwa jika tidak membeli produk tersebut akan merusak konsep dirinya. Misalnya: konsumen selalu membeli pakaian dengan merek tertentu karena merasa pakaian itu mampu mengekspresikan citra dirinya dan konsep dirinya.

\section{Ragam Keputusan Pembelian}

Menurut Hawkins et al, (1998: 27) ada tiga ragam keputusan pembelian, yaitu keputusan pembelian kebiasaan, keputusan pembelian terbatas, dan keputusan pembelian yang diperluas, yang dijelaskan sebagai berikut:

1) Keputusan Pembelian Kebiasaan. Ketika sebuah masalah dikenali, penilaian internal (ingatan jangka panjang) hanya menyediakan satu buah solusi terpilih, kemudian merek tersebut dibeli, dan sebuah evaluasi hanya muncul jika performa merek tersebut tidak sesuai yang diharapkan. Keputusan pembelian kebiasaan muncul ketika ada keterlibatan yang sangat rendah dalam pembelian. Sebuah keputusan pembelian kebiasaan yang lengkap bahkan tidak mempertimbangkan akan alternatif untuk tidak membeli produk tersebut. Keputusan pembelian ini biasa dibagi 
menjadi 2 kategori yang terpisah (Hawkins el al, 1998: 29), yaitu:

a) Keputusan kesetiaan merek. Seorang konsumen pasti pernah mengalami keterlibatan yang tinggi dalam membeli suatu produk, sebagai responnya ia memakai proses keputusan pembelian yang diperluas. Setelah produk itu didapatkan melalui proses pengambilan keputusan yang rumit, konsumen mungkin akan membeli lagi produk tersebut tanpa pertimbangan lebih lanjut. Dengan demikian konsumen terikat dengan produk tersebut karena ia percaya dahulu produk tersebut adalah yang terbaik yang dapat memenuhi semua kebutuhannya dan ia telah membentuk ikatan emosional pada produk tersebut.

b) Keputusan pembelian berulang. Konsumen mungkin percaya bahwa produk satu dengan yang lainnya adalah sama. Dan konsumen mungkin tidak mempunyai banyak kepentingan dikategori produk tersebut atau pembeliannya. Ketika konsumen tersebut telah mencoba salah satu produk kemudian merasa puas, ia akan membelinya lagi kapanpun ia membutuhkannya. Dengan demikian konsumen tersebut telah menjadi pembeli ulang produk, tapi ia tidak terikat dengan produk tersebut.

2) Keputusan Pembelian Terbatas. Keputusan pembelian terbatas muncul untuk merespon kebutuhan lingkungan atau emosional. Konsumen mungkin memutuskan untuk membeli merek baru karena bosan dengan yang digunakan selama ini. Secara umum, keputusan pembelian terbatas melibatkan pengenalan masalah dengan beberapa solusi yang memungkinkan. Terdapat pencarian internal dan eksternal yang terbatas hanya sedikit alternatif yang dievaluasi pada sedikit dimensi yang menggunakan aturan seleksi yang

Eko dan Bisnis (Riau Economics and Business Reviewe) Volume 11, Nomor 3, 27 September 2020 sederhana, dan hanya ada sedikit evaluasi setelah pembelian dan penggunaan produk kecuali jika terdapat kerusakan produk.

3) Keputusan pembelian yang diperluas. Keputusan yang diperluas adalah respon dari keterlibatan pembelian yang tinggi. Terdapat pencarian informasi internal dan eksternal yang luas diikuti dengan evaluasi yang kompleks dari banyak alternatif. Setelah pembelian terdapat keraguan akan ketepatan keputusan yang diambil dan kemudian keputusan pembelian yang mencapai tingkat kerumitan seperti ini. Walaupun begitu, banyak produk seperti rumah, komputer, dan alat-alat rekreasi seringkali dibeli dengan pengambilan keputusan yang diperluas.

\section{Cakupan Keputusan Pembelian}

Keputusan untuk membeli yang diambil oleh konsumen, sebenarnya merupakan kumpulan dari sejumlah keputusan. Menurut Simamora (2002: 76) setiap keputusan membeli terkait lima keputusan, yaitu:

1) Keputusan tentang jenis produk. Konsumen dapat mengambil keputusan untuk membeli bentuk produk yang ditawarkan oleh perusahaan tertentu. Keputusan tersebut menyangkut pula ukuran, mutu, dan corak. Dalam hal ini perusahaan harus melakukan riset pemasaran untuk mengetahui kesukaaan konsumen tentang produk yang bersangkutan agar dapat memaksimalkan daya tarik juga.

2) Keputusan tentang bentuk produk. Konsumen harus mengambil keputusan pembelian berdasarkan bentuk produk yang akan dibeli, dalam hal ini perusahaan harus mengetahui bagaimana membuat visual produk semenarik mungkin.

3) Keputusan tentang merek. Konsumen harus mengambil keputusan tentang merek mana yang akan dibeli, dalam 
hal ini perusahaan harus mengetahui bagaimana memilih sebuah merek.

4) Keputusan tentang penjualnya. Konsumen harus mengambil keputusan dimana produk yang akan dibeli termasuk di dalamnya, yaitu tentang lokasi produk tersebut dijual.

5) Keputusan tentang jumlah produk. Konsumen dapat mengambil keputusan seberapa banyak produk yang akan dibelinya pada suatu saat. Dalam hal ini perusahaan harus mempersiapkan produk sesuai dengan keinginan yang berbeda-beda dari pada konsumen.

6) Tipe-tipe Keputusan Pembelian

Setiap konsumen melakukan berbagai macam keputusan tentang pencarian, pembelian, penggunaan beragam produk, dan merk pada setiap periode tertentu. Berbagai macam aktivitas kehidupan seringkali harus dilakukan oleh setiap konsumen pada setiap hari. Konsumen melakukan keputusan setiap hari atau setiap periode tanpa menyadari bahwa mereka telah mengambil keputusan. Pengambilan keputusan konsumen berbedabeda tergantung pada jenis keputusan pembelian. Menurut Assael (2001: 25) membedakan empat jenis perilaku pembelian konsumen berdasarkan tingkat keterlibatan pembeli dan tingkat perbedaan merek-merek, yang dijelaskan sebagai berikut:

1) Keputusan Pembelian yang Rumit (Complex Decision Making). Perilaku pembelian yang rumit terdiri dari proses tiga langkah. Pertama, pembeli mengembangkan keyakinan tentang produk tersebut. Kedua, pembeli membangun sikap tentang produk tersebut. Ketiga, pembeli membuat pilihan pembelian yang cermat. Konsumen terlibat dalam perilaku pembelian yang rumit bila mereka sangat terlibat dalam pembelian dan sadar akan adanya perbedaan-perbedaan besar diantara merek. Perilaku pembelian yang rumit itu sering terjadi bila produknya mahal, jarang dibeli, berisiko dan sangat mengekspresikan diri.

2) Perilaku Pembelian Pengurang Ketidaknyamanan (Brand Loyalty).

Eko dan Bisnis (Riau Economics and Business Reviewe) Volume 11, Nomor 3, 27 September 2020
Kadang-kadang konsumen sangat terlibat dalam sebuah pembelian namun melihat sedikit perbedaan di antara berbagai merek. Keterlibatan yang tinggi didasari oleh fakta bahwa pembelian tersebut mahal, jarang dilakukan dan berisiko. Dalam kasus ini, pembeli akan berkeliling untuk mempelajari apa yang tersedia namun akan membeli dengan cukup cepat, barangkali pembeli sangat peka terhadap harga atau terhadap kenyamanan berbelanja. Konsumen pada tipe ini, urutan hirarki pengaruhnya adalah: perilaku. Perilaku konsumen tipe ini adalah melakukan pembelian terhadap satu merek tertentu secara berulang-ulang dan konsumen mempunyai keterlibatan yang tinggi dalam proses pembeliannya. Perilaku pembelian seperti ini menghasilkan tipe perilaku konsumen yang loyal terhadap merek (brand loyalty).

3) Perilaku Pembelian yang mencari variasi (Limited Decision Making). Banyak produk dibeli dengan kondisi rendahnya keterlibatan konsumen dan tidak adanya perbedaan merek yang signifikan. Mereka pergi ke toko dan mengambil merek tertentu. Jika mereka tetap mengambil merek yang sama, hal itu karena kebiasaan, bukan karena kesetiaan terhadap merek yang kuat. Terdapat bukti yang cukup bahwa konsumen memiliki keterlibatan yang rendah dalam pembelian sebagian besar produk yang murah dan sering dibeli. Konsumen pada tipe ini, hirarki pengaruhnya adalah kepercayaan, perilaku dan evaluasi. Tipe ini adalah perilaku konsumen yang melakukan pembeliannya dengan pembuatan keputusan, dan pada proses pembeliannya konsumen merasa kurang terlibat. Perilaku pembelian seperti ini menghasilkan tipe perilaku konsumen limited decision making. Konsumen dalam tipe ini akan mencari suatu toko yang menawarkan produk berharga murah, jumlahnya banyak,

P.ISSN: 1410-7988 E.ISSN: 2614-123X 
kupon, contoh cuma-cuma, dan mengiklankan ciri-ciri suatu produk sebagai dasar atau alasan bagi konsumen untuk mencoba sesuatu yang baru.

4) Perilaku pembelian karena kebiasaan (Inertia). Beberapa situasi pembelian ditandai oleh keterlibatan konsumen yang rendah namun perbedaan merek yang signifikan. Dalam situasi itu, konsumen sering melakukan peralihan merek. Konsumen pada tipe ini, urutan hirarki pengaruhnya adalah: kepercayaan kemudian perilaku. Konsumen ini tidak melakukan evaluasi sehingga dalam melakukan pembelian suatu merek produk hanya berdasarkan kebiasaan dan pada saat pembelian konsumen ini kurang terlibat. Perilaku seperti ini menghasilkan perilaku konsumen tipe inertia.

\section{Manfaat Keputusan Pembelian}

Menurut Sutisna (2003: 2) dalam artikel "Proses Pengambilan Keputusan oleh Konsumen" disebutkan manfaat dari adanya keputusan pembelian adalah sebagai berikut:

1) Untuk merancang sebuah strategi pemasaran yang baik, misalnya menentukan kapan saat yang tepat perusahaan memberikan diskon untuk menarik pembeli.

2) Dapat membantu pembuat keputusan membuat kebijakan publik. Misalnya dengan mengetahui bahwa konsumen akan banyak menggunakan transportasi saat lebaran, pembuat keputusan dapat merencanakan harga tiket transportasi di hari raya tersebut.

3) Pemasaran sosial, yaitu penyebaran ide di antara konsumen. Dengan memahami sikap konsumen dalam menghadapi sesuatu, seseorang dapat menyebarkan ide dengan lebih cepat dan efektif.

Dapat disimpulkan bahwa keputusan pembelian adalah tahap proses keputusan dimana konsumen secara aktual melakukan pembelian produk. Keputusan pembelian dalam penelitian ini diukur menggunakan lima indikator yang diadopsi dari Simamora (2002: 76), yang meliputi: keputusan tentang

Eko dan Bisnis (Riau Economics and Business Reviewe) Volume 11, Nomor 3, 27 September 2020 jenis produk, keputusan tentang bentuk produk, keputusan tentang merek, keputusan tentang penjualnya, keputusan tentang jumlah produk.

\section{METODE \\ Tempat Dan Waktu Penelitian}

Penelitian in dilakukan di program DIII Manajemen Perusahaan Universitas Islam Negeri Sultan Syarif Kasim Riau, yang beralamat di Jl. H.R. Soebrantas No. 155 KM. 15 Simpang Baru Panam Pekanbaru. Penelitian ini dilakukan bulan Mei 2019 sampai selesai.

\section{Jenis dan Sumber Data}

Data Primer. Sumber data primer adalah sumber data yang langsung memberikan data kepada pengumpul data. Data primer pada penelitian ini diperoleh dengan menyebarkan kuesioner kepada mahasiswa Program DIII Manajemen Perusahaan UIN Suska Riau.

Data Sekunder. Sumber data sekunder merupakan sumber yang tidak langsung memberikan data kepada pengumpul data, misalnya lewat orang lain atau lewat dokumen. Data sekunder pada penelitian ini diperoleh dari data pada website, bukubuku referensi, dan informasi lain yang berhubungan dengan penelitian.

\section{Teknik Pengumpulan Data}

Untuk mengambil data serta informasi yang dibutuhkan dalam penelitian ini, maka penulis menggunakan teknik sebagai berikut:

Kuesioner. Kuesioner adalah metode pengumpulan data yang dilakukan dengan cara memberikan pertanyaan-pertanyaan kepada responden dengan panduan kuesioner. Kuesioner dalam penelitian ini menggunakan pertanyaan tertutup.

Wawancara. Wawancara juga digunakan untuk memperluas pandangan peneliti tentang data-data lain yang tidak terformulasi dalam kuesioner, Selain itu wawancara juga digunakan untuk melengkapi data yang terkumpul melalui kuesioner.

$$
\text { P.ISSN: 1410-7988 E.ISSN: 2614-123X }
$$




\section{Populasi Dan Sampel}

Populasi. Populasi adalah wilayah generalisasi yang terdiri atas obyek atau subyek yang mempunyai kualitas dan karakteristik tertentu yang ditetapkan oleh peneliti untuk dipelajari dan kemudian ditarik kesimpulannya (Sugiyono, 2011:80). Populasi dalam penelitian ini adalah mahasiswa Program DIII Manajemen Perusahaan UIN Suska Riau yang melakukan pembelian secara online yang berbasis aplikasi.

Sampel. Sampel adalah sebagian objek yang akan diteliti dari keseluruhan objek dari populasi yang ada(Umar,2004:108). Teknik sampling yang digunakan adalah nonprobability sampling dengan cara Snowball sampling. Snowball sampling adalah teknik pengambilan sampling yang mula-mula mengontak beberapa responden potensial dan menanyakan mereka apakah mereka mengenal seseorang dengan karakteristik yang sama yang dicari dalam penelitian ini.

\section{Analisis Data}

Dalam menganalisis data yang diperoleh, penulis menggunakan metode deskriptif kuantitatif, yaitu suatu cara yang dapat menjelaskan hasil penelitian yang ada dengan menggunakan persamaan rumus matematis dan menghubungkannya dengan teori yang ada, kemudian ditarik kesimpulannya.

Persamaan regresi berganda digunakan untuk menggambarkan model hubungan antar variabel bebas dengan variabel tergantungnya. Persamaan regresi ini memuat nilai konstanta atau intercept nilai koefisien regresi atau slope dan variabel bebas lainnya Suliyanto (2011:54).

Pengukuran variabel-variabel yang terdapat dalam model analisis penelitian ini bersumber dari jawaban atas pertanyaan yang terdapat dalam angket. Karena jawaban tersebut bersifat deskriptif, sehingga diberi nilai agar menjadi data kuantitatif.

Penentuan nilai jawaban untuk setiap pertanyaan menggunakan metode Skala
Likert dengan pembobotan setiap pertanyaan sebagai berikut

A. Jika memilih jawaban Sangat Setuju (SS), maka diberi nilai 5

B. Jika memilih jawaban Setuju (S), maka diberi nilai 4

C. Jika memilih jawaban Netral (N), maka diberi nilai 3

D. Jika memilih jawaban Tidak Setuju (TS), maka diberi nilai 2

E. Jika memilih jawaban Sangat Tidak Setuju (STS), maka diberi nilai 1.

Adapun perumusan Regresi linier berganda sebagai berikut:

$\mathrm{Y}=\mathrm{a}+\mathrm{b}_{1} \mathrm{X}_{1}+\mathrm{b}_{2} \mathrm{X}_{2}+\mathrm{e}$

Dimana :

$\mathrm{Y} \quad=$ Keputusan pembelian

a $\quad=$ Konstanta

$X_{1} \quad=$ Kepercayaan

$X_{2} \quad=$ kemudahan

$\mathrm{b}_{1}-\mathrm{b}_{6} \quad=$ KoesifienRegresi

$e \quad=$ Tingkat Kesalahan (eror)

\section{Uji Hipotesis}

Pengujian hipotesis yang digunakan dalam penelitian ini menggunakan analisis regresi linier berganda berdasarkan uji signifikansi parameter individual ( $t$ test), uji signifikansi simultan ( $F$ test), uji koefisien determinasi $\left(R^{2}\right)$. Untuk menguji hipotesis penelitian, maka digunakan analisis regresi linier berganda dengan bantuan software SPSS (Stastitical Product and Service Solution) versi 17.0.

\section{Uji Signifikan Secara Parsial (Uji t)}

Uji signifikansi secara parsial (uji T) ini bertujuan untuk mengetahui seberapa besar pengaruh variabel indenpenden $\mathrm{X} 1$, $\mathrm{X} 2$ dan X3 terhadap variabel dependen (Y) dengan asumsi variabel lainnya adalah konstan. Pengujian ini dilakukan untuk mengetahui besarnya variabel independen secara sendiri-sendiri terhadap variabel dependen Sugiyono (2016:134). Pengujian ini dilakukan dengan membandingkan $t$ yang didapat dari perhitungan dengan nilai $t$ yang ada pada tabel $t$ dengan tingkat 
kesalahan $(\alpha)$ sebesar 5\% dengan kriteria pengambilan keputusan sebagai berikut :

1. Bila $t$ hitung $>t$ tabel dengan nilai signifikan $<0,05$ maka hipotesis diterima

2. Bila $\mathrm{t}$ hitung $<\mathrm{t}$ tabel dengan nilai signifikan $>0,05$ maka hipotesis ditolak

\section{Uji Secara Simultan (Uji F)}

Uji Signifikansi Simultan ini digunakan untuk mengetahui seberapa besar variabel independen (X1, X2 dan X3) secara bersama-sama berpengaruh terhadap variabel dependen (Y). Analisa uji F dilakukan dengan membandingkan $\mathrm{F}$ hitung dan $\mathrm{F}$ tabel. Namun sebelum membandingkan nilai $F$ tersebut, harus ditentukan tingkat kepercayaan (1- $\alpha)$ dan derajat kebebasan (degree of freedom $)=\mathrm{n}-(\mathrm{k}+1)$ agar dapat ditentukan nilai kritisnya. Adapun nilai Alpha yang digunakan dalam penelitian ini adalah sebesar 0,05. Menurut Sugiyono (2016:138) menyatakan kriteria signifikansi secara parsial terhadap variabel penelitian sebagai berikut:

1) Apabila $\mathrm{F}$ hitung $>\mathrm{F}$ tabel atau $\mathrm{P}$ value $<\alpha$ maka:

a) $\mathrm{Ha}$ diterima karena terdapat pengaruh yang signifikan.

b) H0 ditolak karena tidak terdapat pengaruh yang signifikan.

2) Apabila $F$ hitung $<F$ tabel atau $P$ value $>\alpha$ maka:

a) Ha ditolak karena tidak memiliki pengaruh yang signifikan.

b) H0 diterima karena terdapat pengaruh yang signifikan.

\section{Koefisien Determinasi}

Koefisien determinasi digunakan untuk mengetahui persentase variabel independen secara bersamasama dapat menjelaskan variabel dependen. Menurut Sugiyono (2016:146) menyatakan bahwa nilai koefisien determinasi adalah di antara nol dan satu. Jika koefisien determinasi $\left(\mathrm{R}^{2}\right)=1$, artinya variabel independen memberikan informasi yang dibutuhkan

Eko dan Bisnis (Riau Economics and Business Reviewe) Volume 11, Nomor 3, 27 September 2020 untuk memprediksi variabel-variabel dependen.

Untuk menentukan keeratan dari hubungan atau korelasi antar variabel, dapat di lihat pada ketentuan di bawah ini:

1. $0<\mathrm{R} \leq 0,10$, Korelasi sangat rendah/lemah sekali

2. $0,20<\mathrm{R} \leq 0,40, \quad$ Korelasi rendah/lemah tapi pasti

3. $0,40<\mathrm{R} \leq 0,70$, Korelasi yang cukup berarti

4. $0,70<\mathrm{R} \leq 0,90$, Korelasi yang tinggi, kuat

5. $0,90<\mathrm{R} \leq 1,00$, Korelasi sangat tinggi, kuat sekali, dapat diandalkan $\mathrm{R}=1$, Korelasi Sempurna

\section{HASIL}

\section{Regresi Linear Berganda}

Persamaan regresi linear berganda digunakan untuk menggambarkan model hubungan antar variabel bebas dengan variabel terikatnya. Persamaan regresi ini memuat nilai konstanta atau intercept, nilai koefisien regresi atau slope, dan variabel bebasnya. Berdasarkan hasil penelitian, persamaan dalam analisis regresi linier berganda dalam penelitian ini adalah :

\section{Tabel 2 Rekapitulasi Regresi Linear} Berganda

\begin{tabular}{|l|r|r|c|}
\hline \multirow{2}{*}{ Model } & \multicolumn{2}{|c|}{$\begin{array}{c}\text { Unstandardized } \\
\text { Coefficients }\end{array}$} & $\begin{array}{c}\text { Standardized } \\
\text { Coefficients }\end{array}$ \\
\cline { 2 - 4 } & \multicolumn{1}{c|}{ B } & Std. Error & \multicolumn{1}{c|}{ Beta } \\
\hline 1 (Constant) & 7.994 & 1.332 & \\
X1 & .243 & .083 & .301 \\
X2 & .149 & .054 & .283 \\
\hline
\end{tabular}

Sumber: Data olahan, 2019

Berdasarkan tabel 2 tersebut dapat diketahui persamaan regresi sebagai berikut :

$$
\begin{gathered}
\text { Persamaan Regresi Linier Berganda : } \\
Y=a+b_{1} X_{1}+b_{2} X_{2}+\varepsilon \\
Y=7,994+0,243 X_{1}+0,149 X_{2}+\varepsilon
\end{gathered}
$$

Arti angka-angka dalam persamaan regresi di atas adalah :

1. Nilai konstanta (a) sebesar 7,994. Artinya adalah apabila kepercayaan dan kemudahan berbelanja online P.ISSN: 1410-7988 E.ISSN: 2614-123X 
diasumsikan bernilai nol (0), maka keputusan pembelian bernilai sebesar $7,994$.

2. Nilai koefisien regresi 0,243 menyatakan apabila kepercayaan mengalami peningkatan 1 satuan, maka keputusan pembelian berbelanja secara online akan mengalami peningkatan sebesar 0,243.

3. Nilai koefisien regresi 0,149 menyatakan apabila kemudahan mengalami peningkatan 1 satuan, maka keputusan pembelian berbelanja secara online akan mengalami peningkatan sebesar 0,149.

Standar eror $(\varepsilon)$ merupakan variabel acak dan mempunyai distribusi probabilitas yang mewakili semua faktor yang mempunyai pengaruh terhadap $\mathrm{Y}$ tetapi tidak dimasukkan dalam persamaan

\section{Uji Secara Simultan ( Uji F)}

Yaitu dengan menggunakan $\mathrm{F}$ test dengan pendekatan Analysis of Variance (ANOVA) untuk menguji hubungan regresi antara variabel terikat dengan satu atau lebih variabel bebas. Ini dapat dilakukan dengan Keputusan $\mathrm{H}_{0}$ diterima bila Sig $>0,05$ maka tidak signifikan dan $\mathrm{H}_{1}$ : diterima bila Sig < 0,05 maka signifikan. Berikut adalah hasil pengujian regresi linier sederhana dalam penelitian ini didapat statistik sebagai berikut:

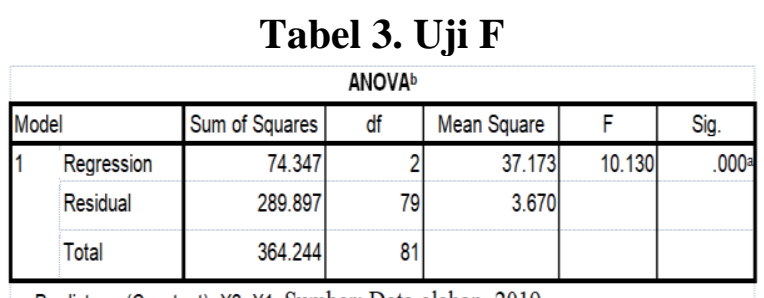

a. Predictors: (Constant), X2, X1. Sumber: Data olahan, 2019

b. Dependent Variable: $Y$

Dari tabel 3 di atas diketahui nilai signifikan sebesar 0,000. Dengan demikian diketahui signifikan $0,000<0,05$. Maka secara simultan atau bersamaan kepercayaan dan kemudahan memiliki pengaruh terhadap keputusan pembelian berbelanja secara online.

\section{Uji Secara Parsial ( Uji T)}

Pengujian ini dilakukan untuk mengetahui besarnya pengaruh variabel independen secara sendiri-sendiri terhadap Eko dan Bisnis (Riau Economics and Business Reviewe) Volume 11, Nomor 3, 27 September 2020 variabel dependen. Pengujian ini dilakukan jika nilai signifikan > 0,05 maka hipotesis ditolak, dan jika nilai signifikan $<0,05$ maka hipotesis diterima.

Berikut adalah hasil pengujian regresi linier sederhana dalam penelitian ini didapat statistik sebagai berikut :

\section{Tabel 4 Rekapitulasi Hasil Pengujian}

Hipotesis Secara Parsial (Uji t)

\begin{tabular}{|c|c|c|c|c|c|c|}
\hline \multicolumn{7}{|c|}{ Coefficients $^{\mathrm{a}}$} \\
\hline \multirow{2}{*}{\multicolumn{2}{|c|}{ Model }} & \multicolumn{2}{|c|}{ Unstandardized Coefficients } & \multirow{2}{*}{$\begin{array}{c}\begin{array}{c}\text { Standardized } \\
\text { Coefficients }\end{array} \\
\text { Beta }\end{array}$} & \multirow[b]{2}{*}{$t$} & \multirow[b]{2}{*}{ Sig. } \\
\hline & & $B$ & Std. Error & & & \\
\hline 1 & (Constant) & 7.994 & 1.332 & & 6.003 & .00 \\
\hline & $\mathrm{X} 1$ & .243 & .083 & .301 & 2.936 & .00 \\
\hline & $\mathrm{X} 2$ & .149 & .054 & .283 & 2.767 & .00 \\
\hline
\end{tabular}

Sumber : Data olahan, 2019

Berdasarkan tabel 4 di atas maka dapat diketahui sebagai berikut :

1. Pengaruh kepercayaan terhadap keputusan pembelian berbelanja secara online menunjukkan nilai signifikan yang dihasilkan sebesar 0,004 masih berada dibawah 0,05. Hal ini menunjukkan bahwa secara parsial kepercayaan memiliki pengaruh terhadap keputusan pembelian berbelanja secara online.

2. Pengaruh kemudahan terhadap keputusan pembelian berbelanja secara online menunjukkan nilai signifikan yang dihasilkan sebesar 0,007 masih berada dibawah 0,05. Hal ini menunjukkan bahwa secara parsial kemudahan memiliki pengaruh terhadap keputusan pembelian berbelanja secara online.

Uji Koefisien Determinasi $\left(\mathbf{R}^{2}\right)$

Koefisien determinasi bertujuan untuk mengukur seberapa besar kemampuan model regeresi dalam menerangkan variasi variabel dependen. Hasil uji koefisien dterminasi dalam penelitihan ini dapat dilihat pada tabel dibawah ini.

Tabel 5 Rekapitulasi Hasil Pengujian Koefisien Determinasi $\left(\mathbf{R}^{2}\right)$

\begin{tabular}{|l|c|r|r|r|}
\hline $\begin{array}{l}\text { Mode } \\
\mathrm{I}\end{array}$ & $\mathrm{R}$ & $\begin{array}{r}\mathrm{R} \\
\text { Square }\end{array}$ & $\begin{array}{c}\text { Adjusted } \mathrm{R} \\
\text { Square }\end{array}$ & $\begin{array}{c}\text { Std. Error of the } \\
\text { Estimate }\end{array}$ \\
\hline 1 & $.452^{\mathrm{a}}$ & .204 & .184 & 1.916 \\
\hline
\end{tabular}

a. Predictors: (Constant), X2, X1

P.ISSN: 1410-7988 E.ISSN: 2614-123X 
Sumber : Data olahan, 2019

Berdasarkan Tabel 5 di atas dapat diketahui bahwa nilai Korelasi (R) yang dihasilkan adalah sebesar 0,452, maka dapat disimpulkan bahwa terdapat hubungan yang cukup kuat antara variabel independen dengan variabel dependen.

Nilai Adjusted $R$ Square sebesar 0,184 atau $18,4 \%$. Ini berarti bahwa kepercayaan dan kemudahan dapat mempengaruhi keputusan pembelian berbelanja secara online sebesar 18,4\%, sementara sisanya dipengaruhi oleh variabel lain yang tidak diteliti dalam penelitian ini.

Penulis melakukan wawancara ke beberapa mahasiswa selaku konsumen untuk mengetahui alasan mereka melakukan belanja online, adapun hasil wawancaranya penulis rangkum sebagai berikut :

1. Hemat waktu dan tenaga. Belanja online dijadikan pilihan akibat tidak punya banyak waktu untuk pergi berbelanja dipusat perbelanjaan, lagipula dengan berbelanja online tidak repot-repot melewati kemacetan dijalan. Selain itu banyaknya aktivitas juga menyebabkan kita tidak memiliki waktu untuk pergi berbelanja keluar rumah, adapun waktu kosong digunakan sebagai waktu istirahat, sehingga dapat menghemat tenaga.

Dengan belanja online, kita bisa melihatlihat barang, hingga bertransaksi kapan saja dan dimana saja. Setelah itu, barang yang dibeli diantar langsung ke alamat sehingga dapat menghemat waktu dan tenaga.

2. Tersedia banyak promo. Menjamurnya e-commerce membuat pelaku toko online memberikan banyak promo untuk menarik pelanggan. Beragam promo yang ditawarkan berbagai tempat belanja inilah yang membuat banyak orang menggandrungi bertransaksi di dunia maya. Jenis promo yang ditawarkan oleh pelaku bisnis online juga beragam, mulai dari berupa potongan harga, poin reward yang bisa ditukarkan, hingga voucher belanja.
3. Punya varian barang yang lebih lengkap. Kadangkala kita berbelanja dipusat perbelanjaan untuk membeli sesuatu, tapi pulang dengan tangan kosong karena barang yang dicari tidak ada, toko konvensional memang seringkali tidak selengkap toko online. Berbeda hal nya dengan toko online yang mana penjualnya datang dari seluruh Indonesia, bahkan penjuru dunia, maka kita bisa mencari barang darimana saja, hingga mancanegara sekalipun.

4. Bisa membandingkan harga barang. Jika kita berbelanja produk yang diinginkan di toko konvensional, tentu akan sulit untuk membandingkan harga satu produk dengan produk lainnya. Lain halnya dengan di toko online, kita tinggal melakukan pencarian nama produk yang kita inginkan maka akan terbuka banyak toko online sekaligus yang menawarkan produk yang sama, lalu kita tinggal membandingkan harganya satu per satu. Bahkan lebih luas lagi kita bisa membandingkan harga dari beberapa situs e-commerce untuk mendapatkan harga yang murah atau yang menawarkan promosi, sehingga kita mendapatkan penawaran terbaik.

Tak bisa dipungkiri, saat ini gaya belanja konsumen mulai beralih dari bertransaksi secara konvensional, kini masyarakat kita lebih suka belanja melalui online. Salah satu faktornya adalah pertumbuhan e-commerce yang juga semakin pesat.

Dari hasil penelitian di atas terlihat bahwa konsumen dalam hal ini mahasiswa banyak yang melakukan berbelanja secara online pada website-website yang berbasis aplikasi. Adapun produk yang dibeli kebanyakan produk-produk fashion, alat kesehatan dan kecantikan, serta elektronik. Hal ini sesuai dengan kebutuhan konsumen yang berada pada usia anak muda. Adapun aplikasi yang banyak dikunjungi adalah shopee, lazada, dan bukalapak. 
Kepercayaan konsumen terhadap website belanja online ini belumlah mendapatkan kepercayaan penuh, hal ini terlihat masih banyaknya konsumen yang menyatakan ragu-ragu / netral terhadap jaminan kepuasan belanja online, keterusterangan penjual atas barang dagangannya, penjual dapat memenuhi janjijanjinya, produk yang dipesan sesuai dengan harapan. Sehingga itu akan mempengaruhi keputusan pembelian berbelanja secara online.

Dilain pihak dari aspek kemudahan dalam penggunaan aplikasi berbelanja online konsumen merasa mudah mempelajari website toko onlinenya, mudahnya dalam penggunaan, kemudahan dalam proses transaksi, mudah dalam memperoleh informasi pada toko online dibandingkan toko offline.

Hal ini menjadi pertimbangan bagi konsumen dalam melakukan keputusan pembelian sehingga dari pengalaman berbelanja online ini konsumen bisa jadi akan melakukan pembelian ulang atau tidak akan melakukan pembelian ulang.

Dari penjelasan di atas maka dapat dikatakan untuk ke depannya belanja secara online ini sangat disukai konsumen dalam memenuhi kebutuhan dan keinginannya akan produk. Tinggal lagi bagaimana toko online ini dapat membangun kepercayaan konsumen dan situs dalam aplikasi mudah untuk digunakan sehingga konsumen memutuskan untuk berbelanja secara online.

\section{SIMPULAN}

1. Konsumen belumlah percaya sepenuhnya melakukan transaksi berbelanja pada toko online yang ada di website.

2. Konsumen sebagian besar (80\%) mengatakan kemudahan mereka berbelanja pada toko online, seperti mudah dipelajari, mudah digunakan, mudah untuk dilakukan, dan mudah untuk memperoleh informasi produk.

3. Sebagian konsumen ada yang akan melakukan pembelian kembali pada toko online dan sebagian lagi tidak akan melakukan pembelian kembali pada toko online yang pernah dikunjunginya.

4. Secara parsial kepercayaan memiliki pengaruh terhadap keputusan pembelian berbelanja secara online.

5. Secara parsial kemudahan memiliki pengaruh terhadap keputusan pembelian berbelanja secara online.

6. Secara simultan atau bersamaan kepercayaan dan kemudahan memiliki pengaruh terhadap keputusan pembelian berbelanja secara online.

7. Kepercayaan dan kemudahan dapat mempengaruhi keputusan pembelian berbelanja secara online sebesar $18,4 \%$, sementara sisanya dipengaruhi oleh variabel lain yang tidak diteliti dalam penelitian ini.

\section{DAFTAR RUJUKAN}

Adityo, Benito dan Khasanah, Imroatul, 2010, Analisis Pengaruh Kepercayaan, Kemudahan, dan Kualitas Informasi Terhadap Keputusan Pembelian Secara Online di Situs Kaskus, Jurnal Semarang : Universitas Diponegoro. Cheng, K.K, et al, 2004, "Using an Online Homework ystem Enhances Students Learning of Physics Consepts in an Introdutory Physcs Course" Journal American Association of Physic Teacher, 72 (11) 1447-1453.

Davis, FD; R.P Bagozzi; P.R Warshaw, 1989, User Acceptance of Computer Tecnology : A Comparison of Two Theoretical Models, Management Science, 35, 8.

Ferrinadewi, Erna, 2008. Merek dan Psikologi Konsumen, Edisi Pertama, Yogyakarta: Graha Ilmu.

Gefen, David, 2002, Customer Loyalty in E-Commerce. Journal of the Association for Information Systems, Vol. 3: Iss. 1, Article 2.

Gefen, F.D; Karahanna, E; dan Straub, D.W, 2003, Trust and TAM In Online Shopping : An Integrated 
Model, MIS Quaterly. Vol. 27 No. 1. March 2003, pp. 51-90.

Handayani,Tri. "Analisis Pengaruh Kepercayaan Konsumen terhadap Persepsi Risiko Belanja Online di Surabaya" (Skripsi-Sekolah Tinggi Ilmu Ekonomi PERBANAS, Surabaya, 2010).

Hasan, Iqbal, 2002, Pokok-pokok Materi Teori Pengambilan Keputusan, Jakarta : Ghalia Indonesia.

Hawkins, D.I., Best, R.J., dan Coney, K.A. 1998. Consumer Behavior, New York: Mac Graw Hill, lnc, USA.

Http://en.Wikipedia.org/

http://www.emarketer.com

http://www.kompasiana.com

Kotler, Philip dan Amstrong Gary, 2008, Prinsip-Prinsip Pemasaran, Jakarta: Erlangga.

Kotler, Philip, 2000, Prinsip-Prinsip Pemasaran, Jilid pertama, Jakarta: Erlangga.

Koufaris, Marios dan Hampton-Sosa, William, 2004. "The Development of Initial Trust in an Online Company by New Costumer", Information and Management 41, pp.377-397.

Rahadi, D.R, 2013, Pengaruh Karateristik Website Terhadap Kepuasan Pelanggan, Jurnal Manajemen dan Binis, Vol. 5, No. 7.

Schiffman, Leon.G. dan Kanuk, Leslie, 2002, Perilaku Konsumen, Jakarta : PT. Indeks.

Simamora, Henry, 2003, Akuntansi Basis Pengambilan Keputusan Bisnis, Jakarta: Salemba Empat.

Soetanto, Jefrey, 2017, Pengaruh kepercayaan, kemudahan, kualitas informasi dan persepsi resiko terhadap keputusan pembelian melalui Situs Jejaring Sosial di Semarang, UNIKA.

Sugiyono, 2016, Metode Penelitian Administrasi, Bandung: Alfabeta. 2011, Metode Penelitian Kuantitatif, Kualitatif dan $R \& D$. Bandung: Alfabeta CV.
Suliyanto, 2011, Ekonometrika TerapanTeori dan Aplikasi dengan SPSS. Yogyakarta: CV. Andi Offset.

Sutisna, 2003, Perilaku Konsumen dan Komunikasi Pemasaran, Bandung : PT. Remaja Rosdakarya.

Suyanto, P, 2003, Analisis Pengaruh Kualitas Layanan dan Citra Merek Terhadap Minat Beli dan Dampaknya pada Keputusan Pembelian, Jurnal Sains Pemasaran Indonesia, Vol. 6, No. 3.

Umar, Husein, 2004, Riset Pemasaran Dan Perilaku Pemasaran, Jakarta : Gramedia Pustaka Utama 